\title{
The Reflection of Manifestations of West Culture in Ahmad Fars Al-Shadiaq's Works
}

\author{
Zahra Khosravi Vamkani ${ }^{1} \&$ Mahdi Najafi Koomleh ${ }^{1}$ \\ ${ }^{1}$ Islamic Azad University of Central Tehran Branch, Tehran, Iran \\ Correspondence: Zahra Khosravi Vamkani, Islamic Azad University of Central Tehran Branch, Tehran, Iran. \\ E-mail: Zah.khosravi_Vamakani@iauctb.ac.ir
}

Received: October 8, 2016

Accepted: October 20, 2016

Online Published: February 14, 2017

doi:10.5539/res.v9n1p219

URL: http://doi.org/10.5539/res.v9n1p219

\begin{abstract}
The most important reasons of the appearance of new literary movements in the Arabic countries can be the collapse of the Ottoman Empire, the dispatch of students and the people's emigration to Europe, the establishment of printing, newspaper and magazine industry.

In fact, the 19th century is the age of awakening of Arabic countries and their relationships with European countries. Meanwhile, thinkers such as Ahmad Fars Shadiaq have attempted more for opening the west civilization gates and advancement of the goals of this movement. In this era, the civilization gates were more opened to all groups living in the society and the cause of dehiscence of potential talents in Arabic countries was provided and it internalized the backgrounds of development, promotion and civil amendments of these countries.
\end{abstract}

In the present study, the attempts have been made to investigate the shut-in-personality of Ahmad Fars Shadiiaq and the reflection of west culture in his works regarding the individual freedoms, social justice and women.

Keywords: Ahmad Fars Shadiq, literary movement, west culture, individual freedoms, social justice, women, the reflection of manifestations of west culture

\section{Introduction}

Nowadays, Arabic societies are indebted to the thinkers and intellectuals, traveling to European countries, observing their scientific developments, asking for revision of their countries social affairs, for the social development of their countries (Rezaee, 2011, p. 9). In fact, the 19th century must be named as the awakening era of Arabic countries by which the Arabic world, connecting to other countries, exiting from literary and intellectual isolation and in some backgrounds, it became in congruence with them. With the collapse of Ottoman Empire, the west civilization gates have been open to the Arabic counties with the help of thinks such as Ahmad Fars Shadiaq and this resulted in literary movement. This development depended on different issues such as the dispatch of students, printing industry, newspapers and magazines and etc. (Fakhori, 2001, p. 12). One result caused by the individuals and students' dispatch to Europe was that the young Arabs could interact with Europeans and their cultures and they closely became familiar with their traditions and scientific and literary development (Hamzeh, 1985, p. 36).

In between, the forerunners such as Shadiaq incited, using the book and newspaper weapons, the Arabic exhausted and mournful society to search. Shadiaq composing books such as "Al Vaseteh Fi Maarafeh Ahval Malete", "Kashf al-Mokhayya", "Al Saq ala al-Saq", etc. and publishing some articles in the newspapers such as "Al Vaqayeh al-Mesrieh", "Al Raed al-Tunesi" and Al-Javaebhas made great attempts for developing Arabic culture and making the people familiar with the culture of European countries.

\section{The Main Question}

What effects did the European culture have on the Shadiaq's works?

\section{The Research Methodology}

In this study, some of the works of Shadiaq and other thinkers were studied and then gained information was analyzed through analytical descriptive method. 


\section{The Review of the Literature}

There are many books regarding Shadiaq and his works but no article has been written with the aforementioned title.

\section{The Biography of Ahmad Fars Shadiaq}

Fars Ebn Yusefebn Mansoorbn Jafar Shaqiq Betros (1801-1887) was title as Shadiaq (Abood, 1950, p. 105). Although there are many view about his birth date. Some believe that Shadiaq was born in (1805) in a village named Ashqoot in Beirut and others believe that he was born in 1801 in a village named Al-hads (Fakhoori, 1991, p. 88). He passed his elementary level of school in the school so named Ayn Varaqe and he learned to speak in Syriac and Hebrew languages (Sheikho, 1991, p. 212). In addition to education, he started to learn calligraphy. In adulthood, he initiated to compose poems. After his father's death, he left school, because of the problems he faced in the life, and started to work out (Abood, 1950, p. 106). After a period of time he started to work as a businessman, but he made his own decision to restudy due to the lack of success in his business (Moqaddesi, 2000, p. 141). In 1826, he went to Egypt due to the invitation of US missions to teach Arabic there (Mojahed, 1994, p. 977). And in Egypt, he learned different types of science by a great professor and after a period of time he started to work in Vaqaye Al-Mesrieh newspaper as an author (Savaya, 1962, p. 24). In 1834, he travelled to the Malt Island and after 14 years living there he went to London for the translation of Torah Book and after that he went to Paris (Solh, 1980, p. 59). Shdiaq moved to Tunisia by the invitation of Baiy Tunes Ahmad Pasha and he composed an ode in praise of Baiy and he accepted the editorial job of a newspaper named Al-Raed al-Tunes. In 1857, he accepted Islam as his religion and was so named Ahmad Fars and he was given a secondary name Abo Abbas (Matavi, 1989, p. 137). Shadiaq left Tunisia to the destination of Istanbul and he established the newspaper of Al-Javaeb and published different types of political and social articles there (Zayyat, Bita, p. 471). Shadiaq had a specific skill and talent in Philology and grammar and composed many poems. He conducted many different works regarding the lexical and grammar topics, criticism and itinerary the most important of which are Alvaseteh fi Maarafe Ahval Maleteh, Kashf al-makhabba an Fonon Europe, Al-saq Ala al-Saq Ma Hova al-Fariaq, Aljasoos ala al-Qamoos and etc. (Zeydan, 1996, p. 250).

Shadiaq compared the issues and problems of new European society with the problems of his own society and he stated those in his own books. One of them is related to the social subject and can be divided as following aspects: 1) individual liberty and its limitation, 2) Religion and society, 3) Social justice, 4) Woman.

\section{The Individual Liberty and Its Limitations}

Observing the cultural and social manifestations of new Europe, Shadiaq was very surprised. He agreed with most of their social issues and he disagreed with the others (Solh, 1980, p. 206). Among those issues that were important regarding his view is the present of the limitation of individual freedom in the society. Regarding the freedom, he has such a view that when the vicious individuals mischief in the society and in this situation, the respected people do not act against them for keeping their honor, this type of freedom causes that the vicious people have superiority to the honorable people so that this type of freedom must not gain currency (Solh, 1980, p. 48). Although this statement does not show that Shadiaq disagreed with the justice among the people; otherwise he believed that all of us are equal regarding the right (Shadiaq, 1982, p. 77). But this equality is not absolute but relative and this justice is something whose springhead is the human's conscience. "It is necessary for the judge to differentiate between vicious people and those who are honorable while he making decision because God did not create humans beings equally but created them in a condition in which some of them have priority than others. Therefore, how can a judge equalize the vicious people with the honorable ones" (Shadiaq, 1299, p. 47).

\section{The Religion in Shadiaq's View}

Shadiaq believes that the religion is necessary for the society because the religion prevent the people from committing the crime and sins and encourages them to do good works and since governor cannot be presented in all places and situations, therefore, in this case, the religion is a preventative factor of preventing cruelty and violation. He stated that the nature of religion is related to the moral virtues and the remoteness from wrong doings and the creation of friendship, love and help to each other (Shadiaq, 1982, p. 124).

Although Shadiaq believed in the religion, he did not have positive attitudes toward some religious men and priest and he believes that most of them are foolish and do not have good morals and behaviors (Khalf Allah, 1955, p. 58). 
Since Shadiaq found that the development of west countries are due to the establishments of printing offices, books and newspapers, he criticized against the religious men of his country due to the lack of attention to this issue because they kept the people to be in ignorance and misdirection (Zarkan, 1988, p. 49).

He declares that it apparently seems that the religious men and the governors do not want their people to acquire the knowledge in order to keep them in misdirection and ignorance otherwise they attempted to establish printing offices in which useful Arabic/non-Arabic books were published (Shadiq, 1982, p. 13). Shadiaq did not disagree with piety and monasticism, but he disagreed with the people who did wickedly and had improper thoughts. He attempted to correct those individuals' behaviors (Jabri, 1987, p. 80). He added that in piety, there is no objection regarding following God and it is a good way but on the condition that the people who want to do that have been 50 years old or more and on the condition that the knowledgeable and wise people enter into it and acquire sciences, then purify their own friends and acquaintances, encourage people to learn the moral issues and good characteristics and behaviors, compose useful books and introduce the ways of achieving salvation and success to the people not like those foolish men who do not understand anything in the world except the misfortune and oldness (Shadiaq, 1982, p. 49). Therefore, in the words of Shadiaq, the necessity of religion for the society and the respect to the pious people are observed, although under some conditions.

\section{The Social Justice in the View of Shadiaq}

Shadiaq, in a chapter of Al-Saq Ala al-Saq which he named "the philosophical thoughts" asked for the social justice but he believed that the social classes must not be eliminated and he, observing the principles of economic and social system of European countries, believed that literarily there is no justice (Solh, 1980, p. 208). Regarding the social classes, he said that it is not possible to deny the existence of rich and poor in the world and they must exist as the beauty and ugliness exist and if they had not been in the world, the living world would have been stopped moving and everything was postponed as the theologians emphasize on it (Shadiaq, 1982, p. 355). He would like his countries to model the European countries in most of social and cultural backgrounds and he says that not only we should buy goods and clothes form the Europeans but also we must buy science and movement from them (Shadiaq, 1982, p. 309). This sentence just stated by Shadiag is the representative of his all reforming thoughts that he wants the people living in his era to buy everything valuable and useful from foreigners.

Shadiaq believes that the people of his country must be similar to the foreigners in most of individual, social aspects he added that the people must be similar to them even in the way of seating and dressing and training their children (Trablosi, 1955, p. 28) although Shadiaq disagrees with the habit of slave trade and the use of maid at home and he considers it as the cause of man and woman's separation as well as the corruption of children of family: "the slaves are the cause of man and woman's divorcing as well as the cause of boys' and girls' corruption". In other hand, the religion disagrees with the slave trade and ethically it is not appropriate to have slaves (Shadiaq, 1916, p. 81/1). In the view of Shadiaq, the abundant wealth causes people to employ maids and this causes the emotional relationship of family to be demolished meaning that the power of wealth destroys the love.

Shadiaq, having exploratory spirit, was seeking for the development, civilization, and democracy in Europe but the civilization and democracy of west did not cause him to ignore the poverty and cruelty of European industrial society and this was the thing which affect had affected more on Shadiaq. He observed the life of farmers in England who were poorer and more miserable than the farmers in his own country (Trablosi, 1995, p. 29). In this case, Shadiaq stated that their farmers are the most miserable creatures of God (Shadiaq, 1982, p. 254). Somewhere else, he also said that the farmers of that land are similar to the tools which are rotating around a specified circle but they do not feel happy and comfortable either while moving or stopping and in Sunday which is the day of happiness and relaxation, they do not have any choices expect for going to the church (Shadiaq, 1982, p. 353). Therefore, Shadiaq, through his own careful attention, not only stated issues related to civilization and development of European society but also pointed out their cruelty and racism.

\section{Woman in the View of Shadiaq}

In today life in which there are claims on supporting women rights in the world, Shadiaq had such an attitude toward them. In fact he was the helper of women and he loved them much as he composed the book of "Al-Saq Ala al-Saq" based on two topics: word and woman (Abood, 1950, p. 196) but the training and social views of Shadiaq in relation to woman can be divided in the following aspects: 1) training woman, 2) Woman's working, 3) The woman's Hijab, 4) Woman's marrying. 


\subsection{Training Woman}

Women in the Arabic countries were secluded in their houses until the middle of 19th century and they were not allowed to be trained and according to the dominated rules in the society, they concealed themselves from strangers but in late 19th century, some ideas and theories related to teaching to women, were posed by the Arabic intellectuals one of which was Shadiaq (Abo Zakri, 1981, p. 269). He asked for observing the Arabic and Muslim women's rights and since the woman as a human being must have the same rights as man does, he first asked for teaching to women (Yasin, 1998, p. 17). Shadiaq believes that the new movement of Europe is closely related to the development of women and their equality to men and he connects the backwardness of eastern countries to the backwardness of women and therefore, he asked for the freedom of women and their equality to the men (Solh, 1980, p. 213). According to Shadiaq, man's responsibility on the woman is not only to supply them with food and clothes but he has other great responsibilities. He also states that it is not good for man regarding the supply of food and clothes for woman as a grace on her and regarding his only responsibility towards her while the woman's rights are more and larger than these issues (Shadiaq, 1982, p. 343). According to him, the most important right of woman is to teach her and he adds that the most significant right of woman is to teach her and remove the curtain of ignorance and illiteracy from her eyes and creates this belief in her that she is like man regarding comprehension and knowledge and she has nothing lesser than him and man must respect to woman because of her knowledge and science. All people know that if woman cannot be able to read and write and to have rules of conduct, she is deceived and in this case, man uses it as a tool for defending himself but if the woman studies useful books, she stops thinking of deceit and trick (Shadiaq, 1982, p. 246). Shadiaq also believes that the woman, learning how to read and write, can cooperate with man in the attitude and work and this causes them to create the love between themselves: "some believe that the woman, learning to read and write, cooperates with the man in the views, work, and interests but I believe that in addition to the aforesaid issues, the knowledge and science increase her tenderness and honesty and prevent her from betraying to the man because first studying books and being aware of the people living past and the people living right now can help us understand the woman's virtues, secondly when woman cooperates with man in views, goals and jobs, she feels that she is a useful person and this finally results in increasing love and tenderness between them. Thirdly, if the woman cooperates with man in works and activities, she avoids doing bad works which the unemployed women usually do (Shadiaq, 1916, p. 15/2). Although Shadiaq asked for teaching to woman, he imposed some for this issue: training our country women is as the same as reading and writing. Undoubtedly, it is better to regard some conditions for carrying it out and is that studying books results in the edification because the women who start to acquire the knowledge avoid thinking of deceiving (Shadiaq, 1982, p. 40). The reason Shadiaq concentrates a lot on the issue of teaching and training woman is that he understood that woman in this society is a main and fundamental element and the illiteracy of this element is regarded as big fault and in the other hand the illiteracy of his woman affected on the attempts he made to progress this movement (Jabri, 1987, p. 86). Therefore, according to Shadiaq, no movement is needed for the eastern countries except for the Woman Movement (Shadiaq, 1916, p. 133/1). This movement is not gained except through teaching to women because when this goal is achieved first the value of woman increases and then the society attitude toward woman changes.

\subsection{The Occupation of Woman}

Woman in the contemporary era and before 1960s was in the conflict between two views of tradition and modernity. In these conflicts, the one who imposed more damages was the woman because some were looking for the cumbersome, and even, superstitious rules and they disagreed with entering woman in the society. Contrary to this first group, there were the modernists such as Shadiaq who were looking for the development of woman simultaneously with the social changes (Abo Saleh, 2011, p. 148).

Shadiaq disagreed with the idea of woman's staying in their houses and states that woman must communicate and cooperate with others and starts to learn one of the arts and an intellectual or physical sciences (Shadiaq, 1982, p. 246). Somewhere else, he states that which woman is satisfied to stay at home similar to a saddled horse which is ready to be ridden and is deprived to cooperate with people (Shadiaq, 1982, p. 268).

Shadiaq wanted the women to be equal to the men in all aspects. In this case, he modelled European countries because he observed that the European new movement had been developed by the equality between man and woman and these two issues had close relationship with each other and if the woman does not understand her importance role in the society and family, it must not be expected that these two issues stay stable and the men are obliged to cooperate with women in works and problems because this causes women to understand and feel the equality between her and the man and her personality becomes complete (Solh, 1980, p. 214). 
Shadiaq who observed different things in European countries asked for the occupation of women and he, about this issue, states that facilitating the women's communication with the men, makes the women able to choose a job, similar to men, for themselves and they can select whatever job they are able to do because when they are dealing with a job, they hardly ever feel lust and since the unemployed women confront sensuality and concupiscence, the unemployment is of the worst vices, because unemployment not only causes the women to speak about nonsense issues but also makes their minds to obsess with the absurd ideas so that nothing can prevent woman from wickedness except having a job and this also approaches woman to the virtue. In the other hand, working causes the body to be healthy (Shadiaq, 1916, p. 126/1).

Therefore, according to Shadiaq, nothing can prevent woman from wickedness except the education and working and this approaches him to the virtues.

\subsection{Woman' Hijab}

Women are a half of world population and the development of woman in each society plays significant role in the promotion of that community but Arabic women were secluded in their houses until the middle of 19th century and the social traditions forced them to cover themselves in order not to be seen by the strangers but in late current century, some theories related to the woman freedom were posed by some thinkers (Abo Zakri, 1982, p. 268). One of these thinkers is Shadiaq who in addition to the idea of training woman focuses on the issue of her Hijab and he was the first person who asked for the woman's unveiling. Shadiaq, according to the unveiling vogue of women in Europe and his observation of unveiling women there, agreed with this culture and attempted to propound this in his own country. He states that "more you cover your wife from being observed by the world eyes, you cannot conceal her from the world heart because wherever and however the woman is, she is the daughter, the mother and the sister of the world. Don't tell me if the woman is a criminal, the book cannot correct her and even increases her sin and fault and if the woman is a good doer, why does she need a book. I mean that your wife was a daughter before she was your wife. No one can ignore the issue that training in childhood is similar to drawing on the stone. Therefore, you must train your children with science, knowledge and virtues" (Shadiaq, 1982, p. 309) meaning that according to Shadiq, training is regarded as a fundamental pillar in the life of a woman but not unveiling or keeping Hijab.

He also insults the mask of women: "although the mask hides the beauty of some women, it helps us not see the ugly women because the ugly women hide their obscenity by putting on it" (Shadiaq, 1982, p. 94). Shadiaq points to this issue in his poems:

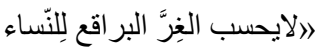

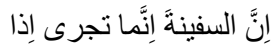

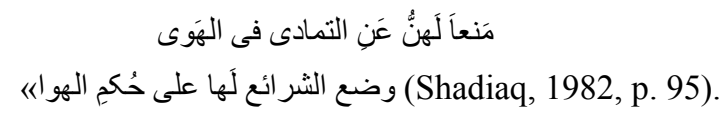

The woman's mask is not regarded as a barrier for the ignorance and misdirection.

The ship can be moved only in the condition that sails are against the wind.

Therefore he, through observing the European countries, believed that mask and Hijab cannot result in the immaculacy in the women but the right training plays an important role in her life.

\subsection{Woman's Marrying}

Shadiaq mentioned many subjects related to the marriage in his books and articles. Since he travelled to different countries, he stated their traditions and customs about marriage (Trablosi, 1995, p. 44). He always used to encourage the young men to marry and forbade them staying single and states that the man who attempts whole of day and is alone at night without having a companion he is deserved to be regarded as a dead (Shadiaq, 1982, p. 222).

Shadiaq adds "whenever a man is married, God causes the man to love his wife anyway as he sees her wife the most beautiful one regarding the face and morality and he thinks of his superiority to his friends and brothers because of this issue" (Shadiaq, 1982, p. 223).

Shadiaq, about marriage, believed that the women and men must be familiar with each other and have relationship with each other before marriage. He also defends the idea of being bounded to one woman. He states that it is logical in the marriage issue that the man has one wife. The biggest evidence to this issue is that when The Dignified God created Adam, he only created one Eve for him, though at that time the earth needed more generation development than the present time. But nowadays, men choose the women as clothes and when the woman is sick or her beauty and youngness decrease, the men divorce the women but when his lust, with the multiple marriages, decreases and his power declines, his grief increases and his ability and competency, due to confronting with difficulties, decrease, he understands that he lost all of his ability to make their wives satisfy as 
well as he lost the ability of doing justice to them. He is similar to a man who kills himself with his own hands (suicide). Therefore, the more the number of wives, the less his ability and competency and the less the number of them, the more financial ability and competency (Shadiaq, 1916, p. 104/1).

Accordingly, he considers the foundation and the base of marriage marrying with only one woman and alarms the consequences of having multiple marriages and bans people from doing it.

\section{Conclusion}

According to the aforementioned subjects by Shadiaq and his works and attempts, it can be stated that he, observing the new cultural and social manifestations of new Europe, was surprised by the social issues and tried to correct his own society and he made many attempts regarding the issues such as individual freedom, religion, social justice, and the woman position. He agrees with the individual freedom if the public interest has been seen there and does not cause the insecurity and violation. In other hand, he considered the religion as a necessary and preventative factor for prohibiting people from doing wickedness and he did not have positive views about some religious man and priests and he criticized their inattention to the printing offices, books and newspapers, which were existed in the European countries, but not in Arabic ones and he believed that religious men and governors did not want their people to learn and acquire sciences and knowledge otherwise they attempted to establish printing offices for them. Regarding the social justice, he wanted the Arabic countries to model European countries. He believed that the Arabic countries must have bought the science and knowledge from those countries.

Shadiaq paid special attention to women and believed that social amendments must be initiated from the issues related to women. Therefore, the woman who was secluded in their houses and was banned being trained in the middle of 19th century, now she had to be helped and strong steps must be taken for her training.

Although he faced the men's disagreements in this matter, he never gave up because he wanted to make the men understand that the woman is similar to man regarding comprehension and knowledge and she has nothing lesser than him and the man must respect her due to her knowledge and science. Although he asked for woman's training, he regards some conditions for this affair. The condition he took was the purification of morality because he believed that women avoid obsessing with the vicious affairs through gaining science and knowledge.

In addition to the science and knowledge, Shadiaq significantly concentrated on the women's occupation although this issue was in the inflict between two ideas of tradition and modernity and the woman imposed the most damages because the society rules and the superstitions of traditionalists closed the hands and legs of women right like shackles and made the women's entrance to the society as occupation overwhelming but Shadiaq, observing the European countries, asked for the women's occupations and considered the women's unemployment as the worst vice and regarded the unemployed women as ones who are talkative and do not think. Shadiaq observing the unveiled women in west countries, insulted the women's hijab in his own country and he believed that mask and hijab cannot gurantee the woman's virtue. He, regarding the marriage, believed that the relationship and familiarity before marriage is necessary and guarantees the success in marriage. He disagreed with the idea of having multiple wives because he believed that man cannot do justice among the wives. Therefore, he believed that choosing one wives is the base and the foundation of marriage and banned men from having multiple wives.

As a result, Shadiaq cleverly recognized that in this era, the women are the fundamental and great pillar in the society and that training the women has a high influence on ascending the movement goals and the social movement toward the development and promotion of Arabic countries. Therefore, he made different attempts regarding this issue to exit the women from the corner of lonely cave of men's captivity in houses and to build a bridge for the development and promotion of Arabic countries to the west civilized world push them in the society by establishing printing offices, schools and newspapers so that he could push his people from ignorance and isolation to happiness and development.

\section{References}

Abd al-Qodos. (2011). NahvMenhaj Islamic Lel Ravaya (1st ed.). Maktab al-Abikan: Riyadh.

Abdol, L. H. (1985). Story of Egyptian Arab Press since its inception to the mid-century. Dar al-Fekr al-Arabi, Cairo.

Ahmad, F. S. (1299). Al Vaseteh Fi Maarafah Ahval Maleteh (2nd ed.). Al Javaeb Publication. 
Ahmad, H. Z. (n.d.). The history of Arabic literature in secondary schools and upper (28th ed.). Dar al-Saqafe: Beirut.

Alab, L. S. (1991). The history of Arabic literature in 19th century. Dar Al Mashreq lel Nashr and al-Tozia.

Al-Biruni. (1991). The summary of Arab literature and history (renaissance modern literature) (2nd ed., Vol. 4). Dar Al-Jalil: Beirut.

Anis, M. (2000). Literary and Media Arts (6th ed.). Dar al-Elm lelMalaeen: Beirut.

Emad, S. (1980). Ahmad Fars al-Shadiaq: Works and era. Dar al-NaharlelNashr: Beirut.

Favaz, T., \& Aziz, A. (1995). Series of unrevealed actions. In Ahmad Fars al-Shadiaq (1st ed.).

Hana, F. (2001). Al Jamea in the history of Arab Literature (Modern Literature) (Vol. 2). Shariat Publication.

Jorji, Z. (1996). The history of Arabic Old Language (1st ed., Vol. 2,). Dar al-Fekr: Beirut.

Marron, A. (1950). Saqr Lebanon: Search in the renaissance and in the modern literary and Ahmad Fars al-Shadiaq. Dar Maroon Ayood.

Mikhaeel, S. (1962). Ahmad Fars al-Shadiaq: Life, works. Dar Al-Mashreq publication, Beirut.

Mohammad, A. H. M. (1989). Ahmad Fars al-Shadiaq: Life, works and Araoh in Arab modern renaissance. Dar al-Qarb al-Islamieh.

Mohammad, A. K. A. (1955). Ahmad Fars al-Shadiaq and linguistic and literary issues. Al-Resaleh Publication.

Mohammad, A. Q. H. (n.d.). Arab Media. In Ahmad Fars al-Shadiaq. Al dar al Mesrieh, lelTarifva al Tarjomeh.

Mohammad, A. Z. (1988). Linguistic aspects of Ahmad Fars al-Shediaq. Dar al-Fekr, Damascus.

RamzanRezaee et al. (2011). Woman in the view of MiZiaeh. The Research and Scientific Quarterly of Woman and Culture, 6 .

Seyyed, M. A. Z. (1981). Article and its development in the contemporary Literature.

Shafiq, J. (1987). Ahmad Fars al-Shediaq (1st ed.). Al-Resaleh Institute: Beirut.

Zaki, M. M. (1994). Sharq Media of fourteen Hijrah (3rd ed., Vol. 3,). Dar al-Qarb al-Islami: Beirut.

\section{Copyrights}

Copyright for this article is retained by the author(s), with first publication rights granted to the journal.

This is an open-access article distributed under the terms and conditions of the Creative Commons Attribution license (http://creativecommons.org/licenses/by/4.0/). 